\title{
Cytokine-Mediated Induction and Regulation of Tissue Damage During Cytomegalovirus Infection
}

\author{
Mathew Clement and lan R. Humphreys* \\ Division of Infection and Immunity/Systems Immunity University Research Institute, Cardiff, United Kingdom
}

Human cytomegalovirus ( $\mathrm{HCMV}$ ) is a $\beta$-herpesvirus with high sero-prevalence within the human population. Primary HCMV infection and life-long carriage are typically asymptomatic. However, HCMV is implicated in exacerbation of chronic conditions and associated damage in individuals with intact immune systems. Furthermore, HCMV is a significant cause of morbidity and mortality in the immunologically immature and immune-compromised where disease is associated with tissue damage. Infection-induced inflammation, including robust cytokine responses, is a key component of pathologies associated with many viruses. Despite encoding a large number

OPEN ACCESS

Edited by:

Juliet Spencer,

Texas Woman's University,

United States

Reviewed by:

Mary Hummel,

Northwestern University, United States

Sarah Rowland-Jones,

University of Oxford, United Kingdom

Laura Kay Hanson,

Texas Woman's University,

United States

*Correspondence:

lan R. Humphreys

humphreysir@cardiff.ac.uk

Specialty section:

This article was submitted to

Viral Immunology,

a section of the journal

Frontiers in Immunology

Received: 14 September 2018

Accepted: 11 January 2019

Published: 29 January 2019

Citation:

Clement M and Humphreys IR (2019)

Cytokine-Mediated Induction and

Regulation of Tissue Damage During

Cytomegalovirus Infection.

Front. Immunol. 10:78.

doi: 10.3389/fimmu.2019.00078 of immune-evasion genes, HCMV also triggers the induction of inflammatory cytokine responses during infection. Thus, understanding how cytokines contribute to $\mathrm{CMV}$-induced pathologies and the mechanisms through which they are regulated may inform clinical management of disease. Herein, we discuss our current understanding based on clinical observation and in vivo modeling of disease of the role that cytokines play in CMV pathogenesis. Specifically, in the context of the different tissues and organs in which CMV replicates, we give a broad overview of the beneficial and adverse effects that cytokines have during infection and describe how cytokine-mediated tissue damage is regulated. We discuss the implications of findings derived from mice and humans for therapeutic intervention strategies and our understanding of how host genetics may influence the outcome of CMV infections.

Keywords: cytokine, cytomegalovirus infection, immunopathologic process, virus, mcmv

\section{INTRODUCTION}

Human cytomegalovirus (HCMV) is a ubiquitous beta-herpesvirus that has co-evolved with its host for millions of years and acquired multiple immune evasion functions that manipulate and hide the virus from host immunity $(1,2)$. Primary HCMV infection and latency in immune-competent hosts is usually asymptomatic (3). Thus, HCMV is typically thought to establish lifelong infection without inducing overt pathology often triggered by other viruses. It is becomingly apparent, however, that chronic HCMV carriage in 'healthy individuals' may exacerbate conditions from general frailty (4) to cardiovascular disease (5).

HCMV causes morbidity and mortality in immune-compromised patients including transplant recipients and HIV co-infected individuals. Solid-state organ or human stem cell transplantation remains challenging as immune suppression can facilitate uncontrolled HCMV reactivation from host and/or donor tissue, resulting in organ pathology and systemic disease (6). HCMV co-infection is the leading cause of vision loss in untreated HIV/AIDS individuals $(7,8)$ and 
remains an issue in patients receiving anti-retroviral therapy (9). HCMV causes gastrointestinal and neurological diseases during HIV co-infection $(7,10)$. Further examples of viralinduced morbidity include congenital infection where HCMV is the leading infectious cause of all congenital birth defects $(11,12)$. Life-long neurological defects ensue, including microcephaly, encephalitis, seizures, and blindness, and HCMV is the leading cause of congenital deafness $(6,12,13)$.

The fact that HCMV preferentially causes disease in immune compromised individuals highlights the importance of immune control of virus replication. Indeed, many HCMVassociated disease manifestations correlate with viral replication and respond to antiviral drug treatment. However, certain syndromes, particularly chronic diseases, do not typically correlate with high HCMV load (14), suggesting that direct cellular destruction by virus is not the sole cause of tissue damage.

Cytokines participate in immune responses to viruses that activate innate immune responses and orchestrate the development of adaptive antiviral immunity. However, uncontrolled cytokine production can cause off-target effects, participating in various immune-driven pathological processes. Due to the limitations of what can be investigated in humans, the murine CMV (MCMV) model has been used for decades to study mechanisms influencing CMV pathogenesis in vivo, including how cytokines orchestrate antiviral immunity [summarized in detail elsewhere (15)]. Herein, we examine evidence from both clinical studies and experimental models of CMV infection showing that although cytokines are required to limit viral replication, they can cause host damage. We discuss these findings in the context of different tissues where damage during CMV infection can ensue and describe the mechanisms that restrict these harmful processes (see Figure 1 for summary).

\section{PRO-INFLAMMATORY CYTOKINES, SYSTEMIC CYTOMEGALOVIRUS- INDUCED DISEASE, AND ORGAN DAMAGE}

Cytokine responses during HCMV viremia have been mostly studied in the transplantation setting where time of virus exposure is known. Following initial replication, sustained type 1 cytokine signatures are observed that are characterized by production of IFN $\gamma$ [in some but not all studies (16)], IL18 and IL-6, and is further accompanied by acute phase protein and chemokine (IP-10) secretion (16, 17). T-cells are implicated as a significant source of type 1 cytokines $(18,19)$. Furthermore, numerous pro-inflammatory chemokines and cytokines, including IL- 6 , are secreted directly following HCMV infection (20). HCMV triggers cytokine production through the stimulation of pattern recognition receptors (PRRs), most notably Toll-like receptor 2 (21), the cytoplasmic DNA sensor STING (22) and IFI16 (23). Mice defective in PRRs mount reduced cytokine responses to MCMV in vivo (24-26). Although differences in the relative contributions of PRRs to the recognition of MCMV and HCMV may exist, these data suggest that innate immune recognition of viral infection by PRRs contributes to HCMV-induced cytokine profiles. Furthermore, in vitro, HCMV stimulation of peripheral blood-derived monocytes increases expression of TLRs, CD14, and adaptor molecules and transcription factors downstream of TLRs (27). Thus, active HCMV replication likely induces systemic pro-inflammatory cytokine responses both following via direct host recognition but also, potentially, by priming the host immune response to respond strongly to unrelated microbial signals.

Given the established role for type 1 cytokines in antiviral immunity, is such a response to CMV infection a bad thing for the host? Certainly, substantial evidence from clinical and experimental studies point toward a protective role for type 1 cytokine responses in cytomegalovirus infections (28-30). However, studies using MCMV show that T-cell responses, particularly $\mathrm{CD}^{+}$T-cells, known to be induced by type 1 cytokines cause substantial tissue damage if insufficiently regulated $(31,32)$. Also, severe inflammatory cytokine responses or "cytokine storms" occur during MCMV hepatitis (33). Thus, these processes may drive acute HCMV-associated diseases. Furthermore, HCMV is implicated in organ rejection (34, 35) and, in cardiac transplants, graft atherosclerosis (36). Experimental studies using MCMV have recapitulated the observation that acute infection and viral reactivation can influence graft longevity $(37,38)$. MCMV reactivation induces expression within the graft of IFN $\alpha$ and IL-12 (37), implying that viral infection may elicit cytokine responses that activate cellular immunity capable of mediating graft rejection. Furthermore, HCMV induces IP-10 and fractalkine production during infection $(17,39)$, both of which are markers of allograft rejection (40).

HCMV establishes life-long infection within multiple host tissues (41) where some genomes are silent but others are transcriptionally active and express many genes (41-43). Immunological data highlights the likelihood that frequent reactivation events occur that re-stimulate the host immune system (44). Subsequently, HCMV may contribute to cytokine mediated inflammatory diseases in latently-infected immune competent individuals via continued gene transcription and reactivation, stimulating immune recognition and subsequent cytokine production. For example, HCMV is implicated in cardiac diseases (45) including atherosclerosis (46) where plaque formation and instability is an inflammatory-driven processes initiated by IFN $\gamma$ (47). HCMV also induces accumulation of virus-specific cytotoxic CD4 ${ }^{+}$T-cells expressing CX3CR1 (48). CX3CR1 binds fractalkine which is expressed by activated endothelium in response to TNF $\alpha$ and IFN $\gamma$ produced by HCMV-specific T-cells (39). Interestingly, the HCMV chemokine receptor homolog US28 also binds fractalkine (49) and may contribute to localized inflammation. Thus, HCMV-induced cytokine and T-cell responses may mediate endothelial damage that in turn promotes vascular diseases and contributes to damage in multiple tissues and organs. Whether such processes underpin other harmful associations of HCMV, such as increased frailty in elderly individuals (4), is unclear.

Cytokines may also indirectly enhance tissue damage by promoting CMV reactivation and subsequent replication. IL-6 promotes HCMV reactivation in dendritic cells via ERK-MAPK 


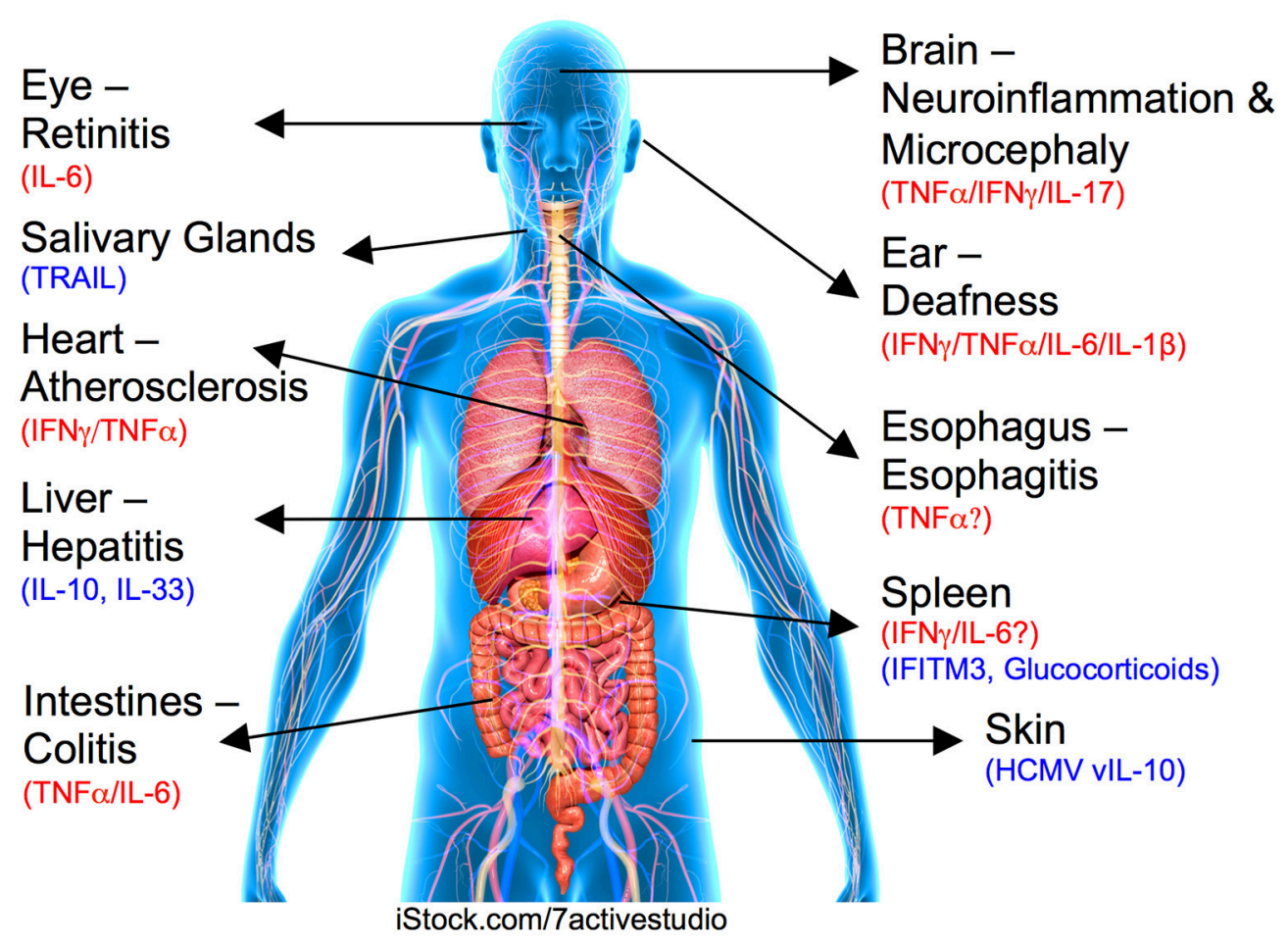

FIGURE 1 | Role for cytokines in CMV-induced organ pathologies. Organ or tissue and associated CMV-induced disease is labeled with inflammatory pathogenic cytokines highlighted in red and regulatory/suppressive pathways shown in blue.

mediated transcriptional induction of major immediate early (IE) genes $(50,51) . T N F \alpha$ and IL-1 $\beta$ also induce IE gene transcription by latent HCMV (52-54) and are implicated in reactivation of HCMV and/or MCMV in vitro and in vivo (55-59). An additional role for IFN $\gamma$ in initiating HCMV reactivation has been described $(56,58)$. Data from MCMV suggest that overt pro-inflammatory cytokine responses may also impinge on innate antiviral immunity. Inadequate proinflammatory cytokine regulation can promote activationinduced NK cell death $(60,61)$ in a process involving IL-6 (60). Thus, inflammatory cytokines may directly and indirectly promote virus replication, which in turn drives peripheral tissue damage.

\section{CYTOKINES AND DAMAGE IN IMMUNE PRIVILEGED SITES}

When HCMV accesses immune privileged organs, immunemediated pathology can ensue. HCMV-induced retinitis is a significant problem in AIDS/HIV patients (7-9). Interestingly, elevated expression of type 1 cytokines including IL- 6 and IFN $\gamma$ in aqueous and/or vitreous fluids from patients is detectable (6264). Systemic CMV infection in immune competent mice induces significant myeloid cell and T-cell infiltrations into ocular tissue including the neural retina (65). Although cytokines likely play a role in mediating these inflammatory processes in immune competent hosts, this has yet to be investigated.
A role for inflammation in HCMV-induced hearing loss in infants is suggested by autopsies showing inner ear inflammation $(66,67)$. In mice, systemic infection of newborns induces progressive hearing loss and decreased spiral ganglia neuron density that is indicative of congenital HCMV infection (68). In MCMV, hearing loss does not correlate with the presence of virus in the cochlea but rather associates with persistent expression of chemokines and pro-inflammatory cytokines including TNF $\alpha$, IL-6, and IL-1 $\beta$ (68). Similarly, intracranial MCMV infection induces hearing loss and chronic inflammatory cytokine expression (69).

Murine neonatal infection models have also been used to recapitulate central nervous system pathology triggered by congenital HCMV infection. After systemic infection, MCMV induces widespread focal encephalitis accompanied by mononuclear inflammation and microglial activation $(70,71)$, including TNF $\alpha$ expression (72). This is accompanied by STAT1 activation and IFN (type I and II) expression, in addition to $\mathrm{TNF} \alpha$ (73). Interestingly, glucocorticoid treatment of these mice reduced cytokine expression and associated morphogenic abnormalities and cellular inflammation without influencing virus load, suggesting that virus-induced inflammation could be safely targeted to improve CMV-induced CNS pathogenesis (73). Indeed, neutralization of $\mathrm{TNF} \alpha$ reduced expression of cytokines and myeloid cell activation and accumulation in the brain, and corrected cerebellar abnormalities and developmental gene expression (74). These important studies provide proof-of-concept that anti-inflammatory approaches 
can be safely utilized to ameliorate CMV pathogenesis in vivo.

HCMV is implicated in esophagitis in HIV-infected individuals and associates with elevated TNF $\alpha$ production (75). Inflammatory bowel diseases are common during HIV co-infection (7) and HCMV maintains active replication in the gastrointestinal epithelium of individuals treated with antiretroviral therapy, where replication disrupts epithelial integrity in a manner partially dependent upon IL-6 (76). HCMV also associates with gastrointestinal inflammation in healthy individuals (77), where the virus may drive local production of cytokines such as TNFa (78) via induction of pattern recognition receptor expression and/or downstream, adaptor molecules $(27,79)$.

HCMV may also impact on neurological diseases in adults, with associations with HIV-associated neurological disorder (HAND) and impaired cognitive performance in HIV-infected individuals being reported [reviewed in (10)]. The link between HCMV and multiple sclerosis in immune competent hosts is controversial, with contradicting findings regarding the association between HCMV seropositivity and disease occurrence (80-82). In the murine experimental autoimmune encephalomyelitis (EAE) experimental model, MCMV worsens disease in genetically susceptible mice (83) and increases EAE occurrence in resistant $(\mathrm{BALB} / \mathrm{c})$ strains. Here, infection increases CD4 T-cell-dependent disease that is associated with IFN $\gamma$ - and IL-17-expressing T-cells (84), further demonstrating that $\mathrm{CMV}$ can exacerbate tissue damage in the central nervous system.

Like many herpesviruses, $\mathrm{HCMV}$ is implicated as a risk factor in Alzheimer's Disease (AD) and cognitive decline (85). PBMCs from HCMV seropositive AD subjects produce more IFN $\gamma$ following polyclonal and viral protein stimulation than non$\mathrm{AD}$ subjects (86), and IFN $\gamma$ is detectable only in cerebrospinal fluid of HCMV seropositive but not seronegative AD patients (87). Thus, although the role of HCMV in AD development is controversial, (88) it appears that HCMV-infected AD sufferers exhibit heightened cytokine responses which in turn could contribute to disease development and/or progression.

\section{REGULATION OF CYTOKINE-DRIVEN CMV-INDUCED PATHOGENESIS}

Despite its inflammatory potential, HCMV rarely causes inflammatory conditions in healthy individuals. Furthermore, infection in immune compromised and immunologically immature hosts does not always cause overt tissue damage, suggesting that virus-induced inflammatory cytokine responses are tightly regulated.

\section{Regulatory T-Cells}

The association between inducible regulatory T-cell (iTregs) expansions and reduced vascular pathology in elderly HCMVinfected individuals suggests a protective function for Tregs in HCMV infection (89). In MCMV, Tregs (promoted by IL-33) restrict liver pathology following systemic MCMV infection (32) and chronic reactive gliosis triggered by MCMV encephalitis (90). Although hepatic Tregs are known to be dependent upon IL-33 (32), whether Treg-mediated control of pathogenic T-cell responses involves restriction of inflammatory cytokine secretion is currently unknown.

\section{Cytokines}

Inflammatory cytokine responses during acute HCMV infection are accompanied by secretion of the immune modulatory cytokine IL-10 (16, 91). HCMV re-programmes human hematopoietic progenitor cells (HPCs) into immune-suppressive monocytes that express IL-10 in a process requiring US28 (92). In mice, genetic and pharmacological targeting of IL10 demonstrates that IL-10 limits systemic inflammatory cytokine responses induced by CMV, including IL- 6 and TNF $\alpha$ (61, 93, 94). This alleviates MCMV-induced disease, assessed using body weight $(93,94)$, and weight loss in IL-10-/- mice is alleviated by TNF $\alpha$ neutralization (93). IL-10 also restricts MCMV-induced hepatic inflammation and preserves liver function by limiting inflammatory effector cell infiltration, hepatocyte apoptosis and necrosis $(95,96)$. Experiments performed in perforin-deficient mice that are unable to control MCMV replication reveal that IL-10 restricts liver inflammation primarily by limiting pathogenic $\mathrm{CD}^{+}{ }^{+} \mathrm{T}$-cell responses (31), a conclusion supported by data derived from immune competent Il- $10^{-/-}$mice (95). Following injection of MCMV into the brain, IL-10 limits fatal immunopathology characterized by proinflammatory cytokine production and neutrophil infiltration (97, 98). Although the physiological relevance of some of these experiments in terms of HCMV pathogenesis is unclear, these data clearly highlight that IL-10R signaling can suppress CMV-induced immune pathology.

Importantly, genetic variation within the human IL-10 gene correlates with altered HCMV disease occurrence following allogeneic stem cell transplantation (99) and during HIV coinfection (100). This suggests that host genetic variation may influence tissue damage caused by HCMV-induced cytokines. Furthermore, HCMV encodes a functional IL-10 otholog (UL111A, vIL-10) that is expressed in lytic replication (101) and an alternate isoform in latency [LAcmvIL-10 (102)]. vIL10 suppresses numerous innate and adaptive host immune responses including pro-inflammatory cytokine secretion (103, 104). Given that cellular IL-10 promotes MCMV carriage (93, 105-107), one may predict that HCMV vIL-10 facilitates virus persistence. However, using rhesus macaque CMV (rhCMV) that, like HCMV but not MCMV, expresses UL111A, it has been demonstrated that vIL-10 restricts acute inflammation at the initial site of infection, the skin. Interestingly, UL111A had no obvious impact on virus shedding in these experiments. This implies that virus persistence may not be influenced by UL111A in vivo (108) but instead that restriction of tissue pathology is an important function of viral IL-10 orthologs and perhaps other immune evasion gene products expressed by HCMV. Intriguingly, certain clinically-isolated HCMV strains have disrupted UL111A genes $(109,110)$. It will be interesting to investigate whether these HCMV strains preferentially associate with overt inflammatory responses. 
IL-27 is an IL-12 family member that restricts numerous infection-induced pathologies (111). IL-27 facilitates MCMV persistence in the mucosa by suppressing IFN $\gamma^{+}(107)$ and/or cytotoxic (112) CD4 ${ }^{+}$T-cells. Given that cytotoxic CD4 ${ }^{+}$T-cells are implicated in tissue damage (113), IL-27-faciliated shedding of virions may be a necessary evil to restrict the development of these cells. Data regarding the function of IL-27 during HCMV infection is limited. Spector and colleagues identified that IL27 limits IFN $\gamma$ expression by virus-specific T-cells in $\mathrm{HIV}^{+}$and $\mathrm{HIV}^{-} \mathrm{HCMV}$-infected individuals. This was accompanied by IL27-mediated induction of IL-10 secreting CD4 ${ }^{+}$T-cells (114). Whether IL-27 also alters the development of HCMV-specific cytotoxic T-cells is unknown. However, overall these data are consistent with the idea that IL-27 restricts chronic tissue damage by limiting HCMV-specific T-cell responses.

Data from HCMV and MCMV highlights that the cytokine TNF-related apoptosis-inducing ligand (TRAIL) contributes to control of virus replication (115-117). During persistent MCMV infection in the salivary glands, however, TRAIL expression by $\mathrm{NK}$ cells restricts pathogenic $\mathrm{CD}^{+}{ }^{+} \mathrm{T}$-cell responses in this tissue. TRAIL-deficient mice exhibit hallmarks of Sjogren's syndrome (SS), an autoimmune disease of the salivary glands that is characterized by ectopic germinal centerlike structures in the glands, elevated autoantibody production and impaired saliva secretion (113). Thus, TRAIL can limit both viral replication and potentially harmful infection-induced inflammatory responses.

\section{Antiviral Restriction Factors}

Interferon induced transmembrane protein 3 (IFITM3) is an antiviral restriction factor that inhibits endocytosisdependent cell entry of numerous viruses (118). IFITM3 polymorphisms associated with reduced function are linked to increased risk of severe viral pathogenesis, most notably influenza-induced disease (119-121). Although IFITM3 does not directly impinge on either MCMV or HCMV replication $(60,122)$, Ifitm $3^{-/-}$mice are dramatically more susceptible to MCMV-driven pathogenesis (60). Disease, which can be fatal, consists of extensive weight loss, transient pulmonary and hepatic mononuclear inflammation, and extensive and irreversible splenic damage. Blocking the action of IL- 6 alleviates pathogenesis in MCMV-infected Ifitm $3^{-/}$mice and also inhibits activation-induced NK cell death and promotes NK cell immunity (60). Thus, it is unclear whether IL-6 drives CMV-induced pathology by promoting tissue damage and/or by impairing cellular antiviral innate immune responses and subsequent control of virus replication. Irrespective, these data again highlight the possible role for genetics in determining host cytokine responsiveness to HCMV and the subsequent disease outcome.

\section{Glucocorticoids}

Endogenous glucocorticoids are steroid hormones produced in the adrenal cortex following activation of the hypothalamicpituitary-adrenal (HPA) axis. Initial inflammatory cytokine responses during acute MCMV infection are accompanied by robust glucocorticoid production $(123,124)$, the maximal release of which is dependent upon virus-induced IL-6 (123). The importance of glucocorticoids in modulating CMV-induced pathogenesis is highlighted in studies where mice are rendered globally deficient in glucocorticoids by adrenalectomy and display increased production of pro-inflammatory cytokines and susceptibility to $\mathrm{TNF} \alpha$-mediated lethal disease (125). Furthermore, glucocorticoid receptor signaling in NK cells, via an axis involving the inhibitory $\mathrm{PD}-1$ receptor, exerts tissue-specific regulation of IFN $\gamma$ production. Here, unrestricted $\mathrm{NK}$ cell expression of IFN $\gamma$ in spleens of mice lacking the glucocorticoid receptor in $\mathrm{NCR}^{+}$cells results in necrotizing splenitis and destruction of the white pulp (124). Although pathology in medically important sites of CMV pathogenesis like the liver were unaffected by this process (124), these data suggest that neuro-immune pathways may be critical for control of cytokine-driven pathogenesis during CMV infection.

\section{CONCLUSIONS}

Many associations exist between production of inflammatory cytokines and CMV-associated pathologies in humans and in experimental systems. Experimental models like MCMV have their limitations in terms of variations in virus genetics (including lacking key immune regulatory genes like vIL10) and the imperfect recreation in mice of HCMV-induced pathologies. However, important predictions regarding roles that cytokines play in virus-induced tissue damage and how inflammatory cytokines are regulated can be derived from these studies. Moving forward, these models will be critical to examine whether targeting CMV-induced inflammation is an effective, safe and viable approach to alleviating pathogenesis. Understanding exactly how cytokines cause tissue damage and how production of these cytokines is regulated will hopefully lead to more refined and effective strategies to help alleviate the pathological consequences of HCMV infection. These studies may also help identify host genetic variations that influence cytokine responsiveness and susceptibility to HCMV disease. Finally, these studies may help form novel hypotheses regarding the possible influence of genetic variation in virus-encoded immune evasion genes on HCMV pathogenesis.

\section{AUTHOR CONTRIBUTIONS}

IRH defined the manuscript focus and structure. MC and IRH wrote and edited the manuscript.

\section{FUNDING}

This work was funded by a Welcome Trust Senior Research Fellowship to Ian Humphreys (207503/Z/17/Z).

\section{ACKNOWLEDGMENTS}

The authors wish to thank Dr. Matthew Reeves for critical reading of this manuscript. 


\section{REFERENCES}

1. Jackson SE, Mason GM, Wills MR. Human cytomegalovirus immunity and immune evasion. Virus Res. (2011) 157:151-60. doi: 10.1016/j.virusres.2010.10.031

2. Stack G, Stacey MA, Humphreys IR. Herpesvirus exploitation of host immune inhibitory pathways. Viruses (2012) 4:1182-201. doi: $10.3390 / \mathrm{v} 4081182$

3. Dupont L, Reeves MB. Cytomegalovirus latency and reactivation: recent insights into an age old problem. Rev Med Virol. (2016) 26:75-89. doi: $10.1002 / \mathrm{rmv} .1862$

4. Thomasini RL, Pereira DS, Pereira FSM, Mateo EC, Mota TN, Guimaraes GG, et al. Aged-associated cytomegalovirus and EpsteinBarr virus reactivation and cytomegalovirus relationship with the frailty syndrome in older women. PLoS ONE (2017) 12:e0180841. doi: 10.1371/journal.pone.0180841

5. Spyridopoulos I, Martin-Ruiz C, Hilkens C, Yadegarfar ME, Isaacs J, Jagger C, et al. CMV seropositivity and T-cell senescence predict increased cardiovascular mortality in octogenarians: results from the Newcastle $85+$ study. Aging Cell (2016) 15:389-92. doi: 10.1111/acel.12430

6. Crough $\mathrm{T}$, Khanna R. Immunobiology of human cytomegalovirus: from bench to bedside. Clin Microbiol Rev. (2009) 22:76-98. doi: 10.1128/CMR.00034-08

7. Jacobson MA, Mills J. Serious cytomegalovirus disease in the acquired immunodeficiency syndrome (AIDS). Clinical findings, diagnosis, and treatment. Ann Intern Med. (1988) 108:585-94. doi: 10.7326/0003-4819-108-4-585

8. Hoover DR, Peng Y, Saah A, Semba R, Detels RR, Rinaldo CR Jr, et al. Occurrence of cytomegalovirus retinitis after human immunodeficiency virus immunosuppression. Arch Ophthalmol. (1996) 114:821-7. doi: 10.1001/archopht.1996.01100140035004

9. Jabs DA, Van Natta ML, Holland GN, Danis R, Studies of the Ocular Complications of AIDS Research Group. Cytomegalovirus retinitis in patients with acquired immunodeficiency syndrome after initiating antiretroviral therapy. Am J Ophthalmol. (2017) 174:23-32. doi: 10.1016/j.ajo.2016.10.011

10. Gianella S, Letendre S. Cytomegalovirus and HIV: A Dangerous Pas de Deux. J Infect Dis. (2016) 214:S67-74. doi: 10.1093/infdis/jiw217

11. Griffiths PD. Burden of disease associated with human cytomegalovirus and prospects for elimination by universal immunisation. Lancet Infect Dis. (2012) 12:790-8. doi: 10.1016/S1473-3099(12)70197-4

12. Hagay ZJ, Biran G, Ornoy A, Reece EA. Congenital cytomegalovirus infection: a long-standing problem still seeking a solution. Am J Obstet Gynecol. (1996) 174:241-5. doi: 10.1016/S0002-9378(96)70401-5

13. Fowler KB. Congenital cytomegalovirus infection: audiologic outcome. Clin Infect Dis. (2013) 57:S182-4. doi: 10.1093/cid/cit609

14. Britt W. Manifestations of human cytomegalovirus infection: proposed mechanisms of acute and chronic disease. Curr Top Microbiol Immunol. (2008) 325:417-70. doi: 10.1007/978-3-540-77349-8_23

15. Biron CA, Tarrio ML. Immunoregulatory cytokine networks: 60 years of learning from murine cytomegalovirus. Med Microbiol Immunol. (2015) 204:345-54. doi: 10.1007/s00430-015-0412-3

16. Sadeghi M, Daniel V, Naujokat C, Schnitzler P, Schmidt J, Mehrabi $\mathrm{A}$, et al. Dysregulated cytokine responses during cytomegalovirus infection in renal transplant recipients. Transplantation (2008) 86:275-85. doi: 10.1097/TP.0b013e31817b063d

17. van de Berg PJ, Heutinck KM, Raabe R, Minnee RC, Young SL, van Donselaar-van der Pant KA, et al. Human cytomegalovirus induces systemic immune activation characterized by a type 1 cytokine signature. J Infect Dis. (2010) 202:690-9. doi: 10.1086/ 655472

18. Villacres MC, Longmate J, Auge C, Diamond DJ. Predominant type $1 \mathrm{CMV}$-specific memory T-helper response in humans: evidence for gender differences in cytokine secretion. Hum Immunol. (2004) 65:476-85. doi: 10.1016/j.humimm.2004.02.021

19. Gamadia LE, Rentenaar RJ, van Lier RA, ten Berge IJ. Properties of CD4(+) T cells in human cytomegalovirus infection. Hum Immunol. (2004) 65:486-92. doi: 10.1016/j.humimm.2004.02.020
20. Dumortier J, Streblow DN, Moses AV, Jacobs JM, Kreklywich CN, Camp D, et al. Human cytomegalovirus secretome contains factors that induce angiogenesis and wound healing. J Virol. (2008) 82:6524-35. doi: 10.1128/JVI.00502-08

21. Compton T, Kurt-Jones EA, Boehme KW, Belko J, Latz E, Golenbock DT, et al. Human cytomegalovirus activates inflammatory cytokine responses via CD14 and Toll-like receptor 2. J Virol. (2003) 77:4588-96. doi: 10.1128/JVI.77.8.4588-4596.2003

22. Ishikawa $\mathrm{H}, \mathrm{Ma} Z$, Barber GN. Sting regulates intracellular DNA-mediated, type I interferon-dependent innate immunity. Nature (2009) 461:788-92. doi: $10.1038 /$ nature 08476

23. Li T, Chen J, Cristea IM. Human cytomegalovirus tegument protein pUL83 inhibits IFI16-mediated DNA sensing for immune evasion. Cell Host Microbe. (2013) 14:591-9. doi: 10.1016/j.chom.2013.10.007

24. Krug A, French AR, Barchet W, Fischer JA, Dzionek A, Pingel JT, et al. TLR9dependent recognition of MCMV by IPC and DC generates coordinated cytokine responses that activate antiviral NK cell function. Immunity (2004) 21:107-19. doi: 10.1016/j.immuni.2004.06.007

25. Tabeta K, Georgel P, Janssen E, Du X, Hoebe K, Crozat K, et al. Tolllike receptors 9 and 3 as essential components of innate immune defense against mouse cytomegalovirus infection. Proc Natl Acad Sci USA. (2004) 101:3516-21. doi: 10.1073/pnas.0400525101

26. Zucchini N, Bessou G, Traub S, Robbins SH, Uematsu S, Akira S, et al. Cutting edge: Overlapping functions of TLR7 and TLR9 for innate defense against a herpesvirus infection. J Immunol. (2008) 180:5799-803. doi: 10.4049/jimmunol.180.9.5799

27. Smith PD, Shimamura M, Musgrove LC, Dennis EA, Bimczok D, Novak L, et al. Cytomegalovirus enhances macrophage TLR expression and MyD88-mediated signal transduction to potentiate inducible inflammatory responses. J Immunol. (2014) 193:5604-12. doi: 10.4049/jimmunol.1302608

28. Gamadia LE, Remmerswaal EB, Weel JF, Bemelman F, van Lier RA, Ten Berge IJ. Primary immune responses to human CMV: a critical role for IFNgamma-producing CD4+ T cells in protection against CMV disease. Blood (2003) 101:2686-92. doi: 10.1182/blood-2002-08-2502

29. Tu W, Chen S, Sharp M, Dekker C, Manganello AM, Tongson EC, et al. Persistent and selective deficiency of $\mathrm{CD} 4+\mathrm{T}$ cell immunity to cytomegalovirus in immunocompetent young children. J Immunol. (2004) 172:3260-7. doi: 10.4049/jimmunol.172.5.3260

30. Walton SM, Mandaric S, Torti N, Zimmermann A, Hengel H, Oxenius A. Absence of cross-presenting cells in the salivary gland and viral immune evasion confine cytomegalovirus immune control to effector CD4 T cells. PLoS Pathog. (2011) 7:e1002214. doi: 10.1371/journal.ppat.1002214

31. Lee SH, Kim KS, Fodil-Cornu N, Vidal SM, Biron CA. Activating receptors promote NK cell expansion for maintenance, IL-10 production, and CD8 T cell regulation during viral infection. J Exp Med. (2009) 206:2235-51. doi: 10.1084/jem.20082387

32. Popovic B, Golemac M, Podlech J, Zeleznjak J, Bilic-Zulle L, Lukic ML, et al. IL-33/ST2 pathway drives regulatory $\mathrm{T}$ cell dependent suppression of liver damage upon cytomegalovirus infection. PLoS Pathog. (2017) 13:e1006345. doi: 10.1371/journal.ppat.1006345

33. Trgovcich J, Stimac D, Polic B, Krmpotic A, Pernjak-Pugel E, Tomac J, et al. Immune responses and cytokine induction in the development of severe hepatitis during acute infections with murine cytomegalovirus. Arch Virol. (2000) 145:2601-18. doi: 10.1007/s007050070010

34. Hodson EM, Jones CA, Webster AC, Strippoli GF, Barclay PG, Kable $\mathrm{K}$, et al. Antiviral medications to prevent cytomegalovirus disease and early death in recipients of solid-organ transplants: a systematic review of randomised controlled trials. Lancet (2005) 365:2105-15. doi: 10.1016/S0140-6736(05)66553-1

35. Cainelli F, Vento S. Infections and solid organ transplant rejection: a cause-and-effect relationship? Lancet Infect Dis. (2002) 2:539-49. doi: 10.1016/S1473-3099(02)00370-5

36. Grattan MT, Moreno-Cabral CE, Starnes VA, Oyer PE, Stinson EB, Shumway NE. Cytomegalovirus infection is associated with cardiac allograft rejection and atherosclerosis. JAMA (1989) 261:3561-6. doi: 10.1001/jama.1989.03420240075030

37. Cook CH, Bickerstaff AA, Wang JJ, Zimmerman PD, Forster MR, Nadasdy $T$, et al. Disruption of murine cardiac allograft 
acceptance by latent cytomegalovirus. Am J Transl. (2009) 9:42-53. doi: $10.1111 / j .1600-6143.2008 .02457 . x$

38. Carlquist JF, Shelby J, Shao YL, Greenwood JH, Hammond ME, Anderson JL. Accelerated rejection of murine cardiac allografts by murine cytomegalovirus-infected recipients. lack of haplotype specificity. J Clin Invest. (1993) 91:2602-8. doi: 10.1172/JCI116499

39. Bolovan-Fritts CA, Trout RN, Spector SA. Human cytomegalovirus-specific CD4+-T-cell cytokine response induces fractalkine in endothelial cells. $J$ Virol. (2004) 78:13173-81. doi: 10.1128/JVI.78.23.13173-13181.2004

40. Zhang Q, Liu YF, Su ZX, Shi LP, Chen YH. Serum fractalkine and interferon-gamma inducible protein-10 concentrations are early detection markers for acute renal allograft rejection. Transl Proc. (2014) 46:1420-5. doi: 10.1016/j.transproceed.2014.02.019

41. Shnayder M, Nachshon A, Krishna B, Poole E, Boshkov A, Binyamin A, et al. Defining the transcriptional landscape during cytomegalovirus latency with single-cell RNA sequencing. MBio (2018) 9:18. doi: 10.1128/mBio.00013-18

42. Cheng S, Caviness K, Buehler J, Smithey M, Nikolich-Zugich J, Goodrum F. Transcriptome-wide characterization of human cytomegalovirus in natural infection and experimental latency. Proc Natl Acad Sci USA. (2017) 114:E10586-95. doi: 10.1073/pnas.1710522114

43. Rossetto CC, Tarrant-Elorza M, Pari GS. Cis and trans acting factors involved in human cytomegalovirus experimental and natural latent infection of CD14 (+) monocytes and CD34 (+) cells. PLoS Pathog. (2013) 9:e1003366. doi: 10.1371/journal.ppat.1003366

44. Klenerman P, Oxenius A. T cell responses to cytomegalovirus. Nat Rev Immunol. (2016) 16:367-77. doi: 10.1038/nri.2016.38

45. Simanek AM, Dowd JB, Pawelec G, Melzer D, Dutta A, Aiello AE. Seropositivity to cytomegalovirus, inflammation, all-cause and cardiovascular disease-related mortality in the United States. PLOS ONE (2011) 6:e16103. doi: 10.1371/journal.pone.0016103

46. Weis M, Kledal TN, Lin KY, Panchal SN, Gao SZ, Valantine HA, et al. Cytomegalovirus infection impairs the nitric oxide synthase pathway: role of asymmetric dimethylarginine in transplant arteriosclerosis. Circulation (2004) 109:500-5. doi: 10.1161/01.CIR.0000109692.16004.AF

47. Hansson GK, Libby P. The immune response in atherosclerosis: a doubleedged sword. Nat Rev Immunol. (2006) 6:508-19. doi: 10.1038/nri1882

48. Pachnio A, Ciaurriz M, Begum J, Lal N, Zuo J, Beggs A, et al. Cytomegalovirus infection leads to development of high frequencies of cytotoxic virus-specific CD4+ T Cells targeted to vascular endothelium. PLoS Pathog. (2016) 12:e1005832. doi: 10.1371/journal.ppat.1005832

49. Kledal TN, Rosenkilde MM, Schwartz TW. Selective recognition of the membrane-bound $\mathrm{CX} 3 \mathrm{C}$ chemokine, fractalkine, by the human cytomegalovirus-encoded broad-spectrum receptor US28. FEBS Lett. (1998) 441:209-14. doi: 10.1016/S0014-5793(98)01551-8

50. Reeves MB, Compton T. Inhibition of inflammatory interleukin- 6 activity via extracellular signal-regulated kinase-mitogen-activated protein kinase signaling antagonizes human cytomegalovirus reactivation from dendritic cells. J Virol. (2011) 85:12750-8. doi: 10.1128/JVI.05878-11

51. Hargett D, Shenk TE. Experimental human cytomegalovirus latency in CD14+ monocytes. Proc Natl Acad Sci USA. (2010) 107:20039-44. doi: 10.1073/pnas.1014509107

52. Forte E, Swaminathan S, Schroeder MW, Kim JY, Terhune SS, Hummel M. Tumor necrosis factor alpha induces reactivation of human cytomegalovirus independently of myeloid cell differentiation following posttranscriptional establishment of latency. MBio (2018) 9:e01560-18. doi: $10.1128 / \mathrm{mBio} .01560-18$

53. O'Connor CM, Murphy EA. A myeloid progenitor cell line capable of supporting human cytomegalovirus latency and reactivation, resulting in infectious progeny. J Virol. (2012) 86:9854-65. doi: 10.1128/JVI.01278-12

54. Hummel M, Zhang Z, Yan S, DePlaen I, Golia P, Varghese T, et al. Allogeneic transplantation induces expression of cytomegalovirus immediate-early genes in vivo: a model for reactivation from latency. J Virol. (2001) 75:481422. doi: 10.1128/JVI.75.10.4814-4822.2001

55. Simon CO, Seckert CK, Dreis D, Reddehase MJ, Grzimek NK. Role for tumor necrosis factor alpha in murine cytomegalovirus transcriptional reactivation in latently infected lungs. J Virol. (2005) 79:326-40. doi: 10.1128/JVI.79.1.326-340.2005
56. Hahn G, Jores R, Mocarski ES. Cytomegalovirus remains latent in a common precursor of dendritic and myeloid cells. Proc Natl Acad Sci USA. (1998) 95:3937-42. doi: 10.1073/pnas.95.7.3937

57. Docke WD, Prosch S, Fietze E, Kimel V, Zuckermann H, Klug C, et al. Cytomegalovirus reactivation and tumour necrosis factor. Lancet (1994) 343:268-9. doi: 10.1016/S0140-6736(94)91116-9

58. Soderberg-Naucler C, Streblow DN, Fish KN, Allan-Yorke J, Smith PP, Nelson JA. Reactivation of latent human cytomegalovirus in CD14(+) monocytes is differentiation dependent. J Virol. (2001) 75:7543-54. doi: 10.1128/JVI.75.16.7543-7554.2001

59. Cook CH, Trgovcich J, Zimmerman PD, Zhang Y, Sedmak DD. Lipopolysaccharide, tumor necrosis factor alpha, or interleukin-1beta triggers reactivation of latent cytomegalovirus in immunocompetent mice. J Virol. (2006) 80:9151-8. doi: 10.1128/JVI.00216-06

60. Stacey MA, Clare S, Clement M, Marsden M, Abdul-Karim J, Kane L et al. The antiviral restriction factor IFN-induced transmembrane protein 3 prevents cytokine-driven CMV pathogenesis. J Clin Invest. (2017) 127:146374. doi: 10.1172/JCI84889

61. Stacey MA, Marsden M, Wang EC, Wilkinson GW, Humphreys IR. IL-10 restricts activation-induced death of NK cells during acute murine cytomegalovirus infection. J Immunol. (2011) 187:2944-52. doi: 10.4049/jimmunol.1101021

62. Schrier RD, Song MK, Smith IL, Karavellas MP, Bartsch DU, Torriani FJ, et al. Intraocular viral and immune pathogenesis of immune recovery uveitis in patients with healed cytomegalovirus retinitis. Retina (2006) 26:165-9. doi: 10.1097/00006982-200602000-00007

63. Iyer JV, Agrawal R, Yeo TK, Gunasekeran DV, Balne PK, Lee B, et al. Aqueous humor immune factors and cytomegalovirus (CMV) levels in CMV retinitis through treatment - The CRIGSS study. Cytokine (2016) 84:56-62. doi: $10.1016 /$ j.cyto.2016.05.009

64. Iyer JV, Connolly J, Agrawal R, Yeo TK, Lee B, Au B, et al. Cytokine analysis of aqueous humor in HIV patients with cytomegalovirus retinitis. Cytokine (2013) 64:541-7. doi: 10.1016/j.cyto.2013.08.006

65. Voigt V, Andoniou CE, Schuster IS, Oszmiana A, Ong ML, Fleming $\mathrm{P}$, et al. Cytomegalovirus establishes a latent reservoir and triggers long-lasting inflammation in the eye. PLoS Pathog. (2018) 14:e1007040. doi: 10.1371/journal.ppat.1007040

66. Davis LE, Johnsson LG, Kornfeld M. Cytomegalovirus labyrinthitis in an infant: morphological, virological, and immunofluorescent studies. J Neuropathol Exp Neurol. (1981) 40:9-19. doi: 10.1097/00005072-198101000-00002

67. Boppana SBW. Cytomegalovirus. in: Newton VE, Vallely PJ, editors. Infection and Hearing Impairment. Sussex: John Wiley and Sons (2006). p. 67-93.

68. Bradford RD, Yoo YG, Golemac M, Pugel EP, Jonjic S, Britt WJ. Murine $\mathrm{CMV}$-induced hearing loss is associated with inner ear inflammation and loss of spiral ganglia neurons. PLoS Pathog. (2015) 11:e1004774. doi: 10.1371/journal.ppat.1004774

69. Schachtele SJ, Mutnal MB, Schleiss MR, Lokensgard JR. Cytomegalovirusinduced sensorineural hearing loss with persistent cochlear inflammation in neonatal mice. $J$ Neurovirol. (2011) 17:201-11. doi: 10.1007/s13365-011-0024-7

70. Koontz T, Bralic M, Tomac J, Pernjak-Pugel E, Bantug G, Jonjic $\mathrm{S}$, et al. Altered development of the brain after focal herpesvirus infection of the central nervous system. J Exp Med. (2008) 205:423-35. doi: $10.1084 /$ jem. 20071489

71. Cekinovic D, Golemac M, Pugel EP, Tomac J, Cicin-Sain L, Slavuljica I, et al. Passive immunization reduces murine cytomegalovirusinduced brain pathology in newborn mice. J Virol. (2008) 82:12172-80. doi: 10.1128/JVI.01214-08

72. Mutnal MB, Hu S, Little MR, Lokensgard JR. Memory T cells persisting in the brain following MCMV infection induce long-term microglial activation via interferon-gamma. J Neurovirol. (2011) 17:424-37. doi: $10.1007 / \mathrm{s} 13365-011-0042-5$

73. Kosmac K, Bantug GR, Pugel EP, Cekinovic D, Jonjic S, Britt WJ. Glucocorticoid treatment of MCMV infected newborn mice attenuates CNS inflammation and limits deficits in cerebellar development. PLoS Pathog. (2013) 9:e1003200. doi: 10.1371/journal.ppat.1003200 
74. Seleme MC, Kosmac K, Jonjic S, Britt WJ. Tumor necrosis factor alpha-induced recruitment of inflammatory mononuclear cells leads to inflammation and altered brain development in murine cytomegalovirus-infected newborn mice. J Virol. (2017) 91:e01983-16. doi: 10.1128/JVI.01983-16

75. Wilcox CM, Harris PR, Redman TK, Kawabata S, Hiroi T, Kiyono H, et al. High mucosal levels of tumor necrosis factor alpha messenger RNA in AIDS-associated cytomegalovirus-induced esophagitis. Gastroenterology (1998) 114:77-82. doi: 10.1016/S0016-5085(98)70635-3

76. Maidji E, Somsouk M, Rivera JM, Hunt PW, Stoddart CA. Replication of CMV in the gut of HIV-infected individuals and epithelial barrier dysfunction. PLoS Pathog. (2017) 13:e1006202. doi: 10.1371/journal.ppat.1006202

77. Kandiel A, Lashner B. Cytomegalovirus colitis complicating inflammatory bowel disease. Am J Gastroenterol. (2006) 101:2857-65. doi: 10.1111/j.1572-0241.2006.00869.x

78. Smith PD, Saini SS, Raffeld M, Manischewitz JF, Wahl SM. Cytomegalovirus induction of tumor necrosis factor-alpha by human monocytes and mucosal macrophages. J Clin Invest. (1992) 90:1642-8. doi: 10.1172/JCI116035

79. Dennis EA, Smythies LE, Grabski R, Li M, Ballestas ME, Shimamura M, et al. Cytomegalovirus promotes intestinal macrophage-mediated mucosal inflammation through induction of Smad7. Mucosal Immunol. (2018) 1694704. doi: 10.1038/s41385-018-0041-4

80. Sanadgol N, Ramroodi N, Ahmadi GA, Komijani M, Moghtaderi A, Bouzari $\mathrm{M}$, et al. Prevalence of cytomegalovirus infection and its role in total immunoglobulin pattern in Iranian patients with different subtypes of multiple sclerosis. N Microbiol. (2011) 34:263-74.

81. Horakova D, Zivadinov R, Weinstock-Guttman B, Havrdova E, Qu J, Tamano-Blanco M, et al. Environmental factors associated with disease progression after the first demyelinating event: results from the multi-center SET study. PLoS ONE (2013) 8:e53996. doi: 10.1371/journal.pone.0053996

82. Sundqvist E, Bergstrom T, Daialhosein H, Nystrom M, Sundstrom P, Hillert J, et al. Cytomegalovirus seropositivity is negatively associated with multiple sclerosis. Mult Scler. (2014) 20:165-73. doi: 10.1177/1352458513494489

83. Vanheusden M, Broux B, Welten SPM, Peeters LM, Panagioti E, Van Wijmeersch B, et al. Cytomegalovirus infection exacerbates autoimmune mediated neuroinflammation. Sci Rep. (2017) 7:663. doi: 10.1038/s41598-017-00645-3

84. Milovanovic J, Popovic B, Milovanovic M, Kvestak D, Arsenijevic A, Stojanovic B, et al. Murine cytomegalovirus infection induces susceptibility to $\mathrm{EAE}$ in resistant $\mathrm{BALB} / \mathrm{c}$ mice. Front Immunol. (2017) 8:192. doi: 10.3389/fimmu.2017.00192

85. Barnes LL, Capuano AW, Aiello AE, Turner AD, Yolken RH, Torrey EF, et al. Cytomegalovirus infection and risk of Alzheimer disease in older black and white individuals. J Infect Dis. (2015) 211:230-7. doi: 10.1093/infdis/jiu437

86. Westman $\mathrm{G}$, Berglund $\mathrm{D}$, Widen $\mathrm{J}$, Ingelsson $\mathrm{M}$, Korsgren $\mathrm{O}$, Lannfelt $\mathrm{L}$, et al. Increased inflammatory response in cytomegalovirus seropositive patients with Alzheimer's disease. PLoS ONE (2014) 9:e96779. doi: 10.1371/journal.pone.0096779

87. Lurain NS, Hanson BA, Martinson J, Leurgans SE, Landay AL, Bennett DA, et al. Virological and immunological characteristics of human cytomegalovirus infection associated with Alzheimer disease. J Infect Dis. (2013) 208:564-72. doi: 10.1093/infdis/jit210

88. Itzhaki RF, Klapper P. Cytomegalovirus: an improbable cause of Alzheimer disease. J Infect Dis. (2014) 209:972-3. doi: 10.1093/infdis/jit665

89. Terrazzini N, Bajwa M, Vita S, Cheek E, Thomas D, Seddiki N, et al. A novel cytomegalovirus-induced regulatory-type T-cell subset increases in size during older life and links virus-specific immunity to vascular pathology. J Infect Dis. (2014) 209:1382-92. doi: 10.1093/infdis/jit576

90. Lokensgard JR, Schachtele SJ, Mutnal MB, Sheng WS, Prasad S, Hu S. Chronic reactive gliosis following regulatory $\mathrm{T}$ cell depletion during acute MCMV encephalitis. Glia (2015) 63:1982-96. doi: 10.1002/glia.22868

91. Nordoy I, Muller F, Nordal KP, Rollag H, Lien E, Aukrust P, et al. The role of the tumor necrosis factor system and interleukin-10 during cytomegalovirus infection in renal transplant recipients. J Infect Dis. (2000) 181:51-7. doi: $10.1086 / 315184$

92. Zhu D, Pan C, Sheng J, Liang H, Bian Z, Liu Y, et al. Human cytomegalovirus reprogrammes haematopoietic progenitor cells into immunosuppressive monocytes to achieve latency. Nat Microbiol. (2018) 3:503-13. doi: 10.1038/s41564-018-0131-9

93. Mandaric S, Walton SM, Rulicke T, Richter K, Girard-Madoux MJ, Clausen $\mathrm{BE}$, et al. vIL-10 suppression of NK/DC crosstalk leads to poor priming of MCMV-specific CD4 T cells and prolonged MCMV persistence. PLoS Pathog. (2012) 8:e1002846. doi: 10.1371/journal.ppat.1002846

94. Oakley OR, Garvy BA, Humphreys S, Qureshi MH, Pomeroy C. Increased weight loss with reduced viral replication in interleukin-10 knock-out mice infected with murine cytomegalovirus. Clin Exp Immunol. (2008) 151:15564. doi: 10.1111/j.1365-2249.2007.03533.x

95. Tang-Feldman YJ, Lochhead GR, Lochhead SR, Yu C, Pomeroy C. Interleukin-10 repletion suppresses pro-inflammatory cytokines and decreases liver pathology without altering viral replication in murine cytomegalovirus (MCMV)-infected IL-10 knockout mice. Inflamm Res. (2011) 60:233-43. doi: 10.1007/s00011-010-0259-4

96. Gaddi PJ, Crane MJ, Kamanaka M, Flavell RA, Yap GS, SalazarMather TP. IL-10 mediated regulation of liver inflammation during acute murine cytomegalovirus infection. PLoS ONE (2012) 7:e42850. doi: 10.1371/journal.pone.0042850

97. Cheeran MC, Mutnal MB, Hu S, Armien A, Lokensgard JR. Reduced lymphocyte infiltration during cytomegalovirus brain infection of interleukin-10-deficient mice. J Neurovirol. (2009) 15:334-42. doi: 10.1080/13550280903062797

98. Mutnal MB, Cheeran MC, Hu S, Little MR, Lokensgard JR. Excess neutrophil infiltration during cytomegalovirus brain infection of interleukin-10-deficient mice. J Neuroimmunol. (2010) 227:101-10. doi: 10.1016/j.jneuroim.2010.06.020

99. Loeffler J, Steffens M, Arlt EM, Toliat MR, Mezger M, Suk A, et al. Polymorphisms in the genes encoding chemokine receptor 5, interleukin10 , and monocyte chemoattractant protein 1 contribute to cytomegalovirus reactivation and disease after allogeneic stem cell transplantation. J Clin Microbiol. (2006) 44:1847-50. doi: 10.1128/JCM.44.5.1847-1850.2006

100. Sezgin E, Jabs DA, Hendrickson SL, Van Natta M, Zdanov A, Lewis RA, et al. Effect of host genetics on the development of cytomegalovirus retinitis in patients with AIDS. J Infect Dis. (2010) 202:606-13. doi: 10.1086/654814

101. Kotenko SV, Saccani S, Izotova LS, Mirochnitchenko OV, Pestka S. Human cytomegalovirus harbors its own unique IL-10 homolog (cmvIL-10). Proc Natl Acad Sci USA. (2000) 97:1695-700. doi: 10.1073/pnas.97.4.1695

102. Jenkins C, Garcia W, Godwin MJ, Spencer JV, Stern JL, Abendroth A, et al. Immunomodulatory properties of a viral homolog of human interleukin-10 expressed by human cytomegalovirus during the latent phase of infection. $J$ Virol. (2008) 82:3736-50. doi: 10.1128/JVI.02173-07

103. Spencer JV, Lockridge KM, Barry PA, Lin G, Tsang M, Penfold ME, et al. Potent immunosuppressive activities of cytomegalovirus-encoded interleukin-10. J Virol. (2002) 76:1285-92. doi: 10.1128/JVI.76.3.1285-1292.2002

104. Slobedman B, Barry PA, Spencer JV, Avdic S, Abendroth A. Virus-encoded homologs of cellular interleukin-10 and their control of host immune function. J Virol. (2009) 83:9618-29. doi: 10.1128/JVI.01098-09

105. Humphreys IR, de Trez C, Kinkade A, Benedict CA, Croft M, Ware CF. Cytomegalovirus exploits IL-10-mediated immune regulation in the salivary glands. J Exp Med. (2007) 204:1217-25. doi: 10.1084/jem.20062424

106. Jones M, Ladell K, Wynn KK, Stacey MA, Quigley MF, Gostick E, et al. IL-10 restricts memory $\mathrm{T}$ cell inflation during cytomegalovirus infection. $J$ Immunol. (2010) 185:3583-92. doi: 10.4049/jimmunol.1001535

107. Clement M, Marsden M, Stacey MA, Abdul-Karim J, Gimeno Brias S, Costa Bento D, et al. Cytomegalovirus-Specific IL-10-Producing CD4+ T cells are governed by type-I IFN-induced IL-27 and promote virus persistence. PLoS Pathog. (2016) 12:e1006050. doi: 10.1371/journal.ppat.1006050

108. Chang WL, Barry PA. Attenuation of innate immunity by cytomegalovirus IL-10 establishes a long-term deficit of adaptive antiviral immunity. Proc Natl Acad Sci USA. (2010) 107:22647-52. doi: 10.1073/pnas.1013794108

109. Cunningham C, Gatherer D, Hilfrich B, Baluchova K, Dargan DJ, Thomson $\mathrm{M}$, et al. Sequences of complete human cytomegalovirus genomes from infected cell cultures and clinical specimens. J Gen Virol. (2010) 91:605-15. doi: 10.1099/vir.0.015891-0

110. Sijmons S, Thys K, Mbong Ngwese M, Van Damme E, Dvorak J, Van Loock $\mathrm{M}$, et al. High-throughput analysis of human cytomegalovirus 
genome diversity highlights the widespread occurrence of gene-disrupting mutations and pervasive recombination. J Virol. (2015). 89:7673-95. doi: 10.1128/JVI.00578-15

111. Yoshida H, Hunter CA. The immunobiology of interleukin-27. Annu Rev Immunol. (2015) 33:417-43. doi: 10.1146/annurev-immunol-032414-112134

112. Wehrens EJ, Wong KA, Gupta A, Khan A, Benedict CA, Zuniga EI. IL-27 regulates the number, function and cytotoxic program of antiviral CD4 T cells and promotes cytomegalovirus persistence. PLoS ONE (2018) 13:e0201249. doi: 10.1371/journal.pone.0201249

113. Schuster IS, Wikstrom ME, Brizard G, Coudert JD, Estcourt MJ, Manzur $\mathrm{M}$, et al. TRAIL $+\mathrm{NK}$ cells control $\mathrm{CD} 4+\mathrm{T}$ cell responses during chronic viral infection to limit autoimmunity. Immunity (2014) 41:646-56. doi: 10.1016/j.immuni.2014.09.013

114. Garg A, Trout R, Spector SA. Human Immunodeficiency virus type-1 myeloid derived suppressor cells inhibit cytomegalovirus inflammation through interleukin-27 and B7-H4. Sci Rep. (2017) 7:44485. doi: 10.1038/srep44485

115. Verma S, Loewendorf A, Wang Q, McDonald B, Redwood A, Benedict CA, et al. Inhibition of the TRAIL death receptor by CMV reveals its importance in NK cell-mediated antiviral defense. PLoS Pathog. (2014) 10:e1004268. doi: 10.1371/journal.ppat.1004268

116. Smith W, Tomasec P, Aicheler R, Loewendorf A, Nemcovicova I, Wang EC, et al. Human cytomegalovirus glycoprotein UL141 targets the TRAIL death receptors to thwart host innate antiviral defenses. Cell Host Microbe. (2013) 13:324-35. doi: 10.1016/j.chom.2013.02.003

117. Stacey MA, Marsden M, Pham NT, Clare S, Dolton G, Stack G, et al. Neutrophils recruited by IL-22 in peripheral tissues function as TRAILdependent antiviral effectors against MCMV. Cell Host Microbe. (2014) 15:471-83. doi: 10.1016/j.chom.2014.03.003

118. Diamond MS, Farzan M. The broad-spectrum antiviral functions of IFIT and IFITM proteins. Nat Rev Immunol. (2013) 13:46-57. doi: 10.1038/nri3344

119. Allen EK, Randolph AG, Bhangale T, Dogra P, Ohlson M, Oshansky CM, et al. SNP-mediated disruption of CTCF binding at the IFITM3 promoter is associated with risk of severe influenza in humans. Nat Med. (2017) 23:975-83. doi: 10.1038/nm.4370
120. Everitt AR, Clare S, Pertel T, John SP, Wash RS, Smith SE, et al. IFITM3 restricts the morbidity and mortality associated with influenza. Nature (2012) 484:519-23. doi: 10.1038/nature10921

121. Zhang YH, Zhao Y, Li N, Peng YC, Giannoulatou E, Jin RH, et al. Interferoninduced transmembrane protein-3 genetic variant rs $12252-\mathrm{C}$ is associated with severe influenza in Chinese individuals. Nat Commun. (2013) 4:1418. doi: $10.1038 /$ ncomms 2433

122. Xie M, Xuan B, Shan J, Pan D, Sun Y, Shan Z, et al. Human cytomegalovirus exploits interferon-induced transmembrane proteins to facilitate morphogenesis of the virion assembly compartment. J Virol. (2015) 89:3049-61. doi: 10.1128/JVI.0 3416-14

123. Ruzek MC, Miller AH, Opal SM, Pearce BD, Biron CA. Characterization of early cytokine responses and an interleukin (IL)-6-dependent pathway of endogenous glucocorticoid induction during murine cytomegalovirus infection. J Exp Med. (1997) 185:1185-92. doi: 10.1084/jem.185.7.1185

124. Quatrini L, Wieduwild E, Escaliere B, Filtjens J, Chasson L, Laprie $\mathrm{C}$, et al. Endogenous glucocorticoids control host resistance to viral infection through the tissue-specific regulation of PD-1 expression on NK cells. Nat Immunol. (2018) 19:954-62. doi: 10.1038/s41590-0180185-0

125. Ruzek MC, Pearce BD, Miller AH, Biron CA. Endogenous glucocorticoids protect against cytokine-mediated lethality during viral infection. J Immunol. (1999) 162:3527-33.

Conflict of Interest Statement: The authors declare that the research was conducted in the absence of any commercial or financial relationships that could be construed as a potential conflict of interest.

Copyright $(02019$ Clement and Humphreys. This is an open-access article distributed under the terms of the Creative Commons Attribution License (CC BY). The use, distribution or reproduction in other forums is permitted, provided the original author(s) and the copyright owner(s) are credited and that the original publication in this journal is cited, in accordance with accepted academic practice. No use, distribution or reproduction is permitted which does not comply with these terms. 